\title{
The effects of whey application on the soil biological properties and plant growth
}

\author{
Ayşen Akay a,*, Durmus Sert ${ }^{b}$
}

a Selcuk University, Faculty of Agriculture, Department of Soil Science and Plant Nutrition, Konya, Turkey

b Necmettin Erbakan University, Faculty of Engineering and Architecture, Dept of Food Engineering, Konya, Turkey

\section{Article Info}

Received : 10.08 .2019

Accepted : 13.08 .2020

\begin{abstract}
Whey is an industrial dairy by-product. Whey proteins present in whey are valuable functional ingredients with a variety of applications. Because of high investment and management costs, many medium and small-scale cheese manufacturing plants choose the way to waste whey by discharging it to land without refining while large companies prefer to evaluate it. In this experiment were investigated the effects of whey application on some growth parameters of test plant and soil biological properties. For this purpose, greenhouse experiment was conducted to determine the effects of different whey powder solution (6\% dry matter) such as no demineralized whey powder (NDWP), 50\% demineralized whey powder (50\% DWP) and whey protein powder (WPP) on maize growth and biological properties of soils using increasing application rates $(0,50,100,150$ and $200 \mathrm{ml} / \mathrm{kg})$ as three replication. At the end of the study generally, all whey treatments influenced the soil microbiological properties in comparison with the control, indicating activation by microorganisms. The addition of different doses of different whey solutions caused a rapid and significant increase in microbial biomass $\mathrm{C}$, soil respiration, dehydrogenase activity and catalase activity in soil; this increase was especially noticeable in soils treated with NDWP and 50\% DWP. Similarly, addition of 50\% DWP to the soil increased values of plant height, fresh plant weight and fresh root weight compared to the control and other whey. Whey has a positive effect on soil biological properties. In conclusion, we can say that this waste product, which has high nutrient element content, could be used in fertilization practices especially as a nitrogen source and multi-perspective studies need to be carried out on this topic.
\end{abstract}

Keywords: Microbial biomass, Soil respiration, Whey powder, Soil biological properties. (c) 2020 Federation of Eurasian Soil Science Societies. All rights reserved

\section{Introduction}

Whey is the liquid that remains after the separation of casein and fat during milk coagulation in cheese production. The composition of whey varies depending on the type of cheese and the production technique or the liquid of curdled milk. Whey can be found in liquid, powder, granule and other solid forms depending on the state of processing. Whey is rich in lactose and serum proteins ( $\alpha$-lactalbumin, $\beta$-lactoglobulin) it includes and is a liquid with high nutritional value. Whey is a left over product whose recovery is highly important and at the same time one of the most important raw materials of the biotechnology sector. Production of $1 \mathrm{~kg}$ of cheese generates approximately $9 \mathrm{~kg}$ of whey (Robbins et al., 1996). The current world production of whey is about 125 million tonnes, in which about $64 \%$ is produced in European countries and 24\% in North America (Naik et al., 2009).

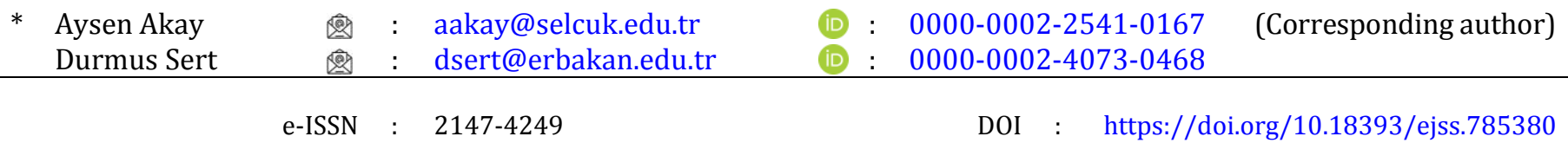


According to the data from 2012, total cheese production in Turkey is 564.031 tons (TUIK, 2012). Although big enterprises prefer to make use of whey, many middle and small scale cheese factories prefer to drain the remaining whey to the land without refining or making use of it due to high investment and operational expenses. Utilization of whey by means of alternative techniques and products is important in terms of the economy, environmental health and nutrition.

It is stated that whey can be used as fertilizer with doing little or no harm to the environment and can be applied to the soil. Several researchers, on the other hand, state that whey would have a positive effect on soil when used as plant nutrient and particularly for fertilization purposes (Watson, 1978; Ryder, 1980; Sienkiewicz and Riedel, 1990) and whey is a nutrient source for agricultural products (Wisconsin Department of Agriculture). Again, some researchers studied the effects of whey on plant development and soil properties and found out that the use of whey improved soil aggregation and maintained an increase in yield in the first and second year after the application (Sharratt et al., 1962; Peterson et al., 1979). Furthermore, the use of whey improves the physical and chemical properties of the soil and increases the aggregate stability and the infiltration rate of sodic soils (Jones et al., 1993; Lehrsch et al., 1994) and acidic soils (Watson et al., 1977; Kelling and Peterson, 1981). Whey increases the infiltration rate in sodic soils by decreasing Exchangeable Sodium Percentage (ESP), Sodium Adsorption Ratio (SAR) and pH values (Jones et al., 1993).

Whey is a good nitrogen source for plant production. The constituents of whey which are important for manuring and microbiological growth are $\mathrm{N}, \mathrm{P}, \mathrm{K}, \mathrm{S}, \mathrm{Ca}, \mathrm{Na}, \mathrm{Mg}$, lactose and proteins (Morris, 1985). It is used for manuring purposes not only to encourage plant growth but may also increase the microorganism population in the soil (Reddy et al., 1987; Özrenk et al., 2003).Whey and straw additions formed higher soil biomass- $\mathrm{C}$ contents and $\mathrm{C}_{\mathrm{mic}} / \mathrm{C}_{\text {org }}$ ratios compared to vegetable oil. Fungal contributions to biomass-C dominated over bacterial contributions in whey and straw-amended soil (Sonnleitner et al., 2003a).

The present study was conducted because there are a limited number of studies on the effects of whey on certain biological characteristics of soil and plant production, the chemical properties of whey give it the potential to be used as a biological fertilizer and some researchers recommend the use of whey as a complete fertilizer (Wendorff, 2012) similar to animal manure. For this purpose, maize was used as test plant in the pot experiment and three whey samples with different properties were regularly applied to the plants after the sowing process. Certain biological properties of the soil were investigated after harvesting the plants.

\section{Material and Methods}

\section{Material}

For this purpose, greenhouse experiment was conducted to determine the effects of different whey powder solutions such as non-demineralized whey powder (NDWP), 50\% demineralized whey powder (50\% DWP) and whey protein powder (WPP) on BC 532 type maize (Zea mays L. indentata S.) growth and biological properties of soils using increasing application rates $(0,50,100,150$ and $200 \mathrm{ml} / \mathrm{kg}$ soil) as three replication. The soil used in the experiment was taken from a depth of 0-20 cm from streambed located in the Campus district of Konya province.

The general analyses of this soil, which was used as growth medium, were conducted at the laboratory of Konya Commodity Exchange. Soil pH was slightly alkaline and calcareous. The soil was salt-free with low organic content and soil texture was sandy-loam (Table 1).

Table 1. Certain physical and chemical characteristics of the soil

\begin{tabular}{llll}
\hline $\mathrm{pH}(1: 2.5)$ & $: 7.46$ & $\mathrm{P}\left(\mathrm{mg} \mathrm{kg}^{-1}\right)$ & $: 3.00$ \\
$\mathrm{EC}\left(1: 5 \mu \mathrm{Cm}^{-1}\right)$ & $: 479$ & $\mathrm{Fe}\left(\mathrm{mg} \mathrm{kg}^{-1}\right)$ & $: 5.87$ \\
Organic matter $(\%)$ & $: 0.125$ & $\mathrm{Cu}\left(\mathrm{mg} \mathrm{kg}^{-1}\right)$ & $: 0.345$ \\
$\mathrm{CaCO}_{3}(\%)$ & $: 10.05$ & $\mathrm{Mn}\left(\mathrm{mg} \mathrm{kg}^{-1}\right)$ & $: 8.677$ \\
$\mathrm{Ca}\left(\mathrm{mg} \mathrm{kg}^{-1}\right)$ & $: 4185$ & $\mathrm{Zn}\left(\mathrm{mg} \mathrm{kg}^{-1}\right)$ & $: 0.216$ \\
$\mathrm{Mg}\left(\mathrm{mg} \mathrm{kg}^{-1}\right)$ & $: 216.7$ & $\mathrm{Na}\left(\mathrm{mg} \mathrm{kg}^{-1}\right)$ & $: 45.08$ \\
$\mathrm{~K}_{2} \mathrm{O}\left(\mathrm{meq} 100 \mathrm{~g}^{-1}\right)$ & $: 0.174$ & & \\
\hline
\end{tabular}

In the experiment, which was set up in the greenhouse in March 2011, 10 maize seeds were planted in each 3-kilogram-pot. After the germination of the plants, a thinning process was applied to leave 6 seedlings in each pot. As mentioned above, three different types of whey powder solutions were applied to the pots in four different doses twice a week [(demineralized whey powder (NDWP), 50\% demineralized whey powder (50\% DWP) and whey protein powder (WPP)]. The whey used in the study was obtained from the producer 
in dried powder form (ENKA Dairy and Food Products Co., Konya, Turkey) and solutions were prepared with water at doses of $0,50,100,150$ and $200 \mathrm{ml} / \mathrm{kg}$ soil before the application and then given to the pots $(6 \%$ dry matter). Also, the test plants were irrigated by using pure water after the planting process. The results of the analysis performed on the whey powder applied to the pots are presented in Table 2. Plants were harvested after 10 weeks; and plant height, weight, growth and root weight were measured. The following analyses were performed on the soils in the pots after the harvesting process.

Table 2. Compositions of whey powder used in the experiments

\begin{tabular}{llll}
\hline Composition & $50 \%$ DWP $^{*}$ & NDWP & WPP \\
\hline Dry matter (\%) & 96.5 & 96.5 & 95 \\
Fat (\%) (\%) & 1 & 0.5 & 6 \\
Protein (\%) & 7 & 6 & 75 \\
Ash (\%) & 4.5 & 9 & 4 \\
Lactose (\%) & 82 & 78 & 6 \\
pH & 6.20 & 6.20 & 6.35 \\
Salt (\%) & 3.5 & 7.0 & 3.4 \\
Coliform bacteria, E. coli, yeast and mold (CFU/g) & 0 & 0 & 0 \\
\hline
\end{tabular}

${ }^{*}$ 50\% DWP: 50\% demineralized whey powder; NDWP: non demineralized whey powder; WPP: whey protein powder

\section{Method}

\section{Microbial biomass carbon and basal soil respiration}

Microbial biomass carbon $\left(\mathrm{C}_{\mathrm{mic}}\right)$ was determined by the substrate-induced respiration method of by Anderson and Domsch (Anderson and Domsch, 1978). The carbon dioxide $\left(\mathrm{CO}_{2}\right)$ production rate was measured hourly using the method described by Anderson (1982). The pattern of respiratory response was recorded for $4 \mathrm{~h}$. Microbial biomass carbon $\left(\mathrm{C}_{\text {mic }}\right)$ was calculated from the maximum initial respiratory response in terms of $\mathrm{mg} \mathrm{C} \mathrm{g}^{-1}$ soil as $40.04 \mathrm{mg} \mathrm{CO}_{2} \mathrm{~g}^{-1}+3.75$. Data are expressed as $\mathrm{mg} \mathrm{C} \mathrm{g}^{-1}$ dry sample.

Basal soil respiration (BSR) at field capacity $\left(\mathrm{CO}_{2}\right.$ production at $22{ }^{\circ} \mathrm{C}$ without addition of glucose) was measured, as reported by Anderson (1982), by alkali [barium hydroxide $\left[\mathrm{Ba}(\mathrm{OH})_{2} \cdot 8 \mathrm{H}_{2} \mathrm{O}\right]+$ barium chloride $\left.\left(\mathrm{BaCl}_{2}\right)\right]$ absorption of the $\mathrm{CO}_{2}$ produced during the $24 \mathrm{~h}$ incubation period, followed by titration of the residual $\mathrm{OH}^{-}$with standardized hydrochloric acid, after adding three drops of phenolphthalein as an indicator. Data are expressed as $\mathrm{mg} \mathrm{CO}_{2}-\mathrm{C} \mathrm{g}^{-1}$ dry sample.

\section{Enzyme activities}

Dehydrogenase activity (DHA) was determined according to Pepper et al. (1995). To $6 \mathrm{~g}$ of sample, $30 \mathrm{mg}$ of glucose, $1 \mathrm{~mL}$ of $3 \%$ TTC (2,3,5 triphenyltetrazoliumchlorid) solution, and $2.5 \mathrm{~mL}$ of pure water were added. The samples were incubated for $24 \mathrm{~h}$ at $37^{\circ} \mathrm{C}$. The formation of TPF (1,3,5 triphenylformazan) was determined spectrophotometrically at $485 \mathrm{~nm}$, and results are expressed as $\mu \mathrm{g}$ TPF g-1 dry sample.

Catalase activity (CA) was measured by the method of Beck (1971). Ten mL of phosphate buffer (pH 7) and $5 \mathrm{~mL}$ of a $3 \%$ hydrogen peroxide $\left(\mathrm{H}_{2} \mathrm{O}_{2}\right)$ substrate solution were added to $5 \mathrm{~g}$ of sample. The volume $(\mathrm{mL})$ of $\mathrm{O}_{2}$ released within $3 \mathrm{~min}$ at $20^{\circ} \mathrm{C}$ was determined. Three replicates of each sample were tested, and controls were tested in the same way, but with the addition of $2 \mathrm{~mL}$ of $6.5 \%(\mathrm{w} / \mathrm{v}) \mathrm{NaN}_{3}$. Results are expressed as $\mathrm{mL}$ $\mathrm{O}_{2} \mathrm{~g}^{-1}$ dry sample.

\section{Analysis of minerals}

In the analysis of minerals, a microwave system (MARS 5, CEM Corporation, Matthews, NC) was used for acid digestion of all the plants. Samples were prepared in triplicate runs (Anonymous, 1998). Mineral concentrations (mg kg-1) were determined by inductively coupled plasma atomic emission spectrometry (CCD Simultaneous ICP-AES, Varian, Palo Alto, CA) with an automatic sampler system. Nitrogen contents of samples were analyzed with Kjeldahl N method (Jones, 2001).

\section{Colour measurements}

Colour measurements were performed using a Minolta Chroma Meter CR-400 (Minolta, Osaka, Japan). Light/dark chromaticity ( $\left.\mathrm{L}^{*}\right)$, green/red chromaticity $\left(\mathrm{a}^{*}\right)$ and blue/yellow chromaticity $\left(\mathrm{b}^{*}\right)$ were determined according to the CIELab colour space system. The instrument was calibrated with a white reference tile $\left(L^{*}=97.10, a^{*}=-4.88, b^{*}=7.04\right)$ before the measurements (Wrolstad and Smith, 2014).

\section{Statistical analysis}

The data obtained through the measurements were statistically analyzed using Minitab and Mstat software (Yurtsever, 1984).

\section{Results}


Significant changes were observed in plant weight depending on the use of different whey solutions (Table $3)(p<0.01)$. The highest mean value was observed in plants in which $50 \%$ DWP solution was used. Plant weights increased depending on the increasing doses of 50\% DWP solution. The use of NDWP solution above $100 \mathrm{mg} / \mathrm{kg}$ caused significant decreases in plant weights. Considering plant weight values, it was determined that the use of WPP solution at $50 \mathrm{ml} / \mathrm{kg}$ would be suitable. Plant root weights varied between approximately 27.72-43.90 g. The lowest root weight was observed in plants with $200 \mathrm{ml} / \mathrm{kg}$ application of NDWP solution. Increasing doses of $50 \%$ DWP solution did not cause significant differences in root weights $(\mathrm{p}>0.01)$.

Table 3. The effect of whey applications on plant growing parameters and soil biological properties

\begin{tabular}{|c|c|c|c|c|c|c|c|}
\hline $\begin{array}{c}\text { Whey } \\
\text { applications* }\end{array}$ & $\begin{array}{l}\text { Whey doses } \\
\text { (ml/kg soil) }\end{array}$ & $\begin{array}{r}\text { Plant } \\
\text { weight (g) }\end{array}$ & $\begin{array}{r}\text { Root } \\
\text { weight (g) }\end{array}$ & Cmic & BSR & $\mathrm{CA}$ & DHA \\
\hline \multirow{6}{*}{$50 \%$ DWP } & 0 & $32.87 \mathrm{c \dagger}$ & 33.98 & $12.06^{d}$ & $0.86^{\mathrm{d}}$ & $163.39 \mathrm{c}$ & $1.74^{\mathrm{c}}$ \\
\hline & 50 & $38.30^{c}$ & 35.80 & $16.96^{d}$ & $1.80^{c}$ & $203.03^{b}$ & $4.42^{b}$ \\
\hline & 100 & $41.96 \mathrm{bc}$ & 37.69 & $33.74^{c}$ & $2.32^{c}$ & $292.71^{\text {a }}$ & $7.26^{\mathrm{a}}$ \\
\hline & 150 & $53.44 \mathrm{ab}$ & 50.31 & $44.91^{b}$ & $3.59 \mathrm{~b}$ & $177.63 \mathrm{bc}$ & $7.81^{a}$ \\
\hline & 200 & $60.68^{a}$ & 49.04 & $69.41^{a}$ & $4.91^{a}$ & $157.14^{c}$ & 7.32 a \\
\hline & Mean & 45.45 & $41.36^{A \neq}$ & $35.42 \mathrm{~A}$ & $2.70^{\mathrm{A}}$ & $198.78^{\text {в }}$ & $5.71^{\mathrm{C}}$ \\
\hline \multirow{6}{*}{ NDWP } & 0 & $41.47^{b}$ & $35.01^{a}$ & $11.60 \mathrm{~d}$ & $0.84 \mathrm{~d}$ & $153.52^{c}$ & $2.43^{c}$ \\
\hline & 50 & 81.19 a & 54.93 a & 42.98 a & $1.53^{c}$ & 304.97 a & $14.82^{a}$ \\
\hline & 100 & 68.23 a & 43.07 a & $30.13^{b}$ & $2.17 \mathrm{~b}$ & 255.52 b & $11.51^{b}$ \\
\hline & 150 & $5.80^{c}$ & $4.96^{b}$ & $22.36^{c}$ & $2.48^{a}$ & $174.02^{c}$ & $9.96^{b}$ \\
\hline & 200 & $0.81^{c}$ & $0.64 \mathrm{~b}$ & $16.44 \mathrm{~d}$ & $2.02 \mathrm{~b}$ & $162.72^{c}$ & $10.17^{b}$ \\
\hline & Mean & 39.50 & $27.72^{\text {в }}$ & $24.70^{\text {в }}$ & $1.81^{\mathrm{B}}$ & $210.15^{\mathrm{A}}$ & $9.78^{\mathrm{A}}$ \\
\hline \multirow{6}{*}{ WPP } & 0 & $46.65^{a}$ & $43.79 \mathrm{ab}$ & $19.38^{d}$ & $0.86^{\mathrm{d}}$ & 153.67 a & $1.48^{\mathrm{d}}$ \\
\hline & 50 & 53.49 a & 55.94 a & $29.60^{c}$ & $1.61^{c}$ & 139.03 a & $5.47^{c}$ \\
\hline & 100 & $33.34 \mathrm{~b}$ & $38.74 \mathrm{~b}$ & $32.68^{c}$ & $2.33 \mathrm{a}$ & $111.91^{b}$ & $8.09 \mathrm{~b}$ \\
\hline & 150 & $33.63^{b}$ & 34.37 b & 44.77 b & $2.11^{b}$ & $85.38^{c}$ & 9.91 a \\
\hline & 200 & $42.48 \mathrm{ab}$ & $46.64 \mathrm{ab}$ & 61.89 a & $1.80^{c}$ & $57.14^{d}$ & 9.95 a \\
\hline & Mean & 41.92 & $43.90 \mathrm{~A}$ & $37.66^{\mathrm{A}}$ & $1.74^{\mathrm{B}}$ & $109.43^{C}$ & $6.98^{\mathrm{B}}$ \\
\hline
\end{tabular}

Cmic: Microbial biomass C (mg CO $2-\mathrm{C} / \mathrm{g}$ dry soil 24h); BSR : Basal soil respiration ( $\mathrm{mg} \mathrm{CO}_{2}-\mathrm{C} / \mathrm{g}$ dry soil 24h);

CA : Catalase activity ( $\mathrm{ml} \mathrm{O}$ /g dry soil $3 \mathrm{~min}$.); DHA: Dehydrogenase activity (mg TPF/g dry soil 24h)

* 50\% DWP: 50\% demineralized whey powder; NDWP: non demineralized whey powder; WPP: whey protein powder

$\dagger$ Means in the same columns with different small letters are significantly different $(p<0.01)$ into same application.

₹ Means in the same columns with different capital letters are significantly different $(p<0.01)$ among different applications

Plant growth rates (\%) are presented in Figure 1. An increase was observed in the growth rate in plants with $50 \%$ DWP application depending on the rate of usage. The use of NDWP resulted in the lowest plant growth rate. Shoot development was not observed in plants through $200 \mathrm{ml} / \mathrm{kg}$ application.

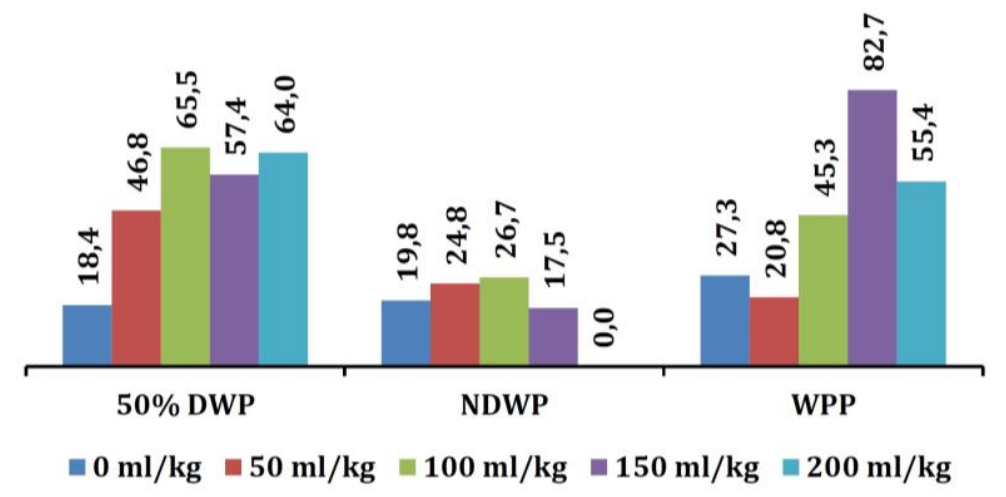

Figure 1. Plant growth rates (\%)

The highest growth rate was observed in plants with $150 \mathrm{ml} / \mathrm{kg}$ WPP application. Basal soil respiration values varied between $0.84-4.91 \mathrm{mg} \mathrm{CO}-\mathrm{C} / \mathrm{g}$ dry soil. The highest mean value was observed with the use of $50 \%$ DWP solution and significantly increased depending on the usage rate of $50 \%$ DWP $(\mathrm{p}<0.01)$. The same tendency was observed also in other whey solutions. The respective 150 and $100 \mathrm{ml} / \mathrm{kg}$ soil overdoses of NDWP and WPP solutions caused a decrease in basal soil respiration values. The catalase activity of the soils was significantly affected by the use of different whey solutions $(\mathrm{p}<0.01)$. The highest mean value $(210.15 \mathrm{ml}$ $\mathrm{O}_{2} / \mathrm{g}$ ) was determined in soils with the use of NDWP solution. The $100 \mathrm{ml} / \mathrm{kg}$ soil overdose of $50 \%$ DWP solution caused significant decreases in catalase activity. The lowest catalase activity values in the soil samples were observed through the use of WPP solution. The increasing use of WPP and NDWP solutions 
caused sharp decreases in catalase activity. The dehydrogenase activity in the soil samples reached the highest mean values through the use of NDWP $>$ WPP $>50 \%$ DWP solutions. All whey solution applications resulted in higher dehydrogenase activity compared to control samples. In contrast to other solutions, the increasing use of NDWP caused a significant decrease in dehydrogenase activity $(\mathrm{p}<0.01)$. For $50 \%$ DWP solution, doses of $150-200 \mathrm{ml} / \mathrm{kg}$ soil provided similar dehydrogenase activities ( $\mathrm{p}>0.01)$. The highest mean $\mathrm{N}$ content in plants was observed in the samples with 50\% DWP application (Table 4).

Table 4. The effect of whey applications on plant mineral contents

\begin{tabular}{|c|c|c|c|c|c|c|c|c|c|c|c|c|}
\hline \multirow{2}{*}{$\begin{array}{c}\text { Whey } \\
\text { applications* }\end{array}$} & \multirow{2}{*}{$\begin{array}{l}\text { Whey doses } \\
\text { (ml/kg soil) }\end{array}$} & \multicolumn{3}{|c|}{$\%$} & \multicolumn{8}{|c|}{$\mathrm{mg} / \mathrm{kg}$} \\
\hline & & $\mathrm{N}$ & $\mathrm{K}$ & $\mathrm{P}$ & $\overline{\mathrm{Ca}}$ & $\mathrm{Mg}$ & $\mathrm{S}$ & $\mathrm{Fe}$ & $\mathrm{Zn}$ & $\mathrm{Mn}$ & $\mathrm{Cu}$ & B \\
\hline \multirow{6}{*}{$50 \%$ DWP } & 0 & 1.71 & $3.12^{a b}$ & 1.09 & 5800 & 2582 & 3070 & 105.3 & 11.23 & 68.49 & 2.52 & 14.72 \\
\hline & 50 & 1.13 & $1.45 \mathrm{~b}$ & 0.54 & 8658 & 2566 & 3036 & 308.1 & 17.45 & 92.80 & 3.39 & 14.45 \\
\hline & 100 & 1.62 & 3.71 a & 1.33 & 5396 & 2421 & 3072 & 115.7 & 15.71 & 77.06 & 3.23 & 12.78 \\
\hline & 150 & 2.51 & $3.38 \mathrm{a}$ & 1.07 & 7224 & 2717 & 3018 & 228.7 & 17.35 & 92.98 & 4.62 & 15.20 \\
\hline & 200 & 2.25 & $2.92 \mathrm{ab}$ & 0.96 & 7207 & 2933 & 2997 & 87.2 & 17.28 & 67.49 & 3.61 & 21.68 \\
\hline & Mean & $1.84^{\mathrm{A}}$ & 2.92 & 0.99 & 6857 & $2644^{\mathrm{A}}$ & $3038^{A}$ & 169.0 & 15.80 & 79.76 & 3.47 & $15.76^{\mathrm{A}}$ \\
\hline \multirow{6}{*}{ NDWP } & 0 & $2.22^{\mathrm{a}}$ & 2.85 & 0.76 & 5854 b & $2895 \mathrm{ab}$ & $3060^{a}$ & 113.6 & $30.66^{b}$ & 67.78 & $2.96 \mathrm{ab}$ & 13.15 bc \\
\hline & 50 & $1.97 \mathrm{ab}$ & 2.41 & 0.51 & 5732 b & $2564 \mathrm{~b}$ & $3022 \mathrm{ab}$ & 94.8 & $11.92^{\mathrm{b}}$ & 58.92 & $2.15^{b}$ & $14.58 \mathrm{abc}$ \\
\hline & 100 & $1.03^{c}$ & 2.50 & 0.83 & $5160^{\mathrm{b}}$ & $2340^{b}$ & $2982 a b c$ & 101.8 & $45.59^{a b}$ & 61.16 & $1.70^{b}$ & $11.78^{c}$ \\
\hline & 150 & $1.27 \mathrm{bc}$ & 2.57 & 0.57 & $6983 \mathrm{ab}$ & $3451^{a}$ & 2939 c & 117.1 & $76.90^{a}$ & 63.98 & $4.64 \mathrm{a}$ & 19.92 a \\
\hline & 200 & $1.08^{c}$ & 2.75 & 0.70 & 8294 a & 3477 a & 2943 bc & 139.9 & $26.95^{b}$ & 66.59 & $4.63^{a}$ & $17.88 \mathrm{ab}$ \\
\hline & Mean & $1.51^{\text {в }}$ & 2.62 & 0.67 & 6405 & $2945^{A}$ & 2989 A & 113.4 & 38.40 & 63.69 & 3.22 & $15.46^{\mathrm{A}}$ \\
\hline \multirow{6}{*}{ WPP } & 0 & $1.85^{\mathrm{a}}$ & 3.03 & 0.87 & 6783 & 2408 & $2944^{a}$ & 75.9 & $18.46^{\mathrm{b}}$ & 64.05 & 2.88 & 14.24 \\
\hline & 50 & $1.13^{b}$ & 2.88 & 0.76 & 4585 & 1982 & $2610^{b}$ & 83.6 & $44.76^{a}$ & 66.27 & 1.67 & 12.22 \\
\hline & 100 & $1.53 \mathrm{ab}$ & 2.77 & 0.63 & 4757 & 2059 & $2646^{b}$ & 55.6 & $29.24 \mathrm{ab}$ & 62.00 & 1.64 & 12.39 \\
\hline & 150 & $1.23 \mathrm{ab}$ & 2.69 & 0.74 & 6381 & 2555 & $2801 \mathrm{ab}$ & 87.5 & $30.90 \mathrm{ab}$ & 57.70 & 2.82 & 9.52 \\
\hline & 200 & $1.32 \mathrm{ab}$ & 3.43 & 1.23 & 6066 & 2036 & $2823 \mathrm{ab}$ & 73.4 & $33.87 \mathrm{ab}$ & 77.56 & 1.83 & 10.04 \\
\hline & Mean & $1.41^{\mathrm{B}}$ & 2.96 & 0.85 & 5714 & $2208^{B}$ & 2765 в & 75.2 & 31.45 & 65.52 & 2.17 & $11.68^{\text {в }}$ \\
\hline
\end{tabular}

\footnotetext{
* 50\% DWP: 50\% demineralized whey powder; NDWP: non demineralized whey powder; WPP: whey protein powder

$\dagger$ Means in the same columns with different small letters are significantly different $(p<0.01)$ into same application.

₹ Means in the same columns with different capital letters are significantly different $(p<0.01)$ among different applications.
}

The increasing use of NDWP solution significantly decreased the $N$ content $(p<0.01)$. The use of WPP solution at doses of $100-200 \mathrm{ml} / \mathrm{kg}$ soil revealed an $\mathrm{N}$ accumulation close to that in the control group. $\mathrm{P}, \mathrm{Fe}$ and $\mathrm{Mn}$ contents of the plants were found to be between $0.51-1.33,55.6-308.1$ and $57.70-92.80 \mathrm{mg} / \mathrm{kg}$, respectively. The use of 50\% DWP and WPP solutions did not cause any significant differences in the $\mathrm{Ca}, \mathrm{Mg}$, $\mathrm{Cu}$ and $\mathrm{B}$ contents of the plants. Compared to the control group, the use of NDWP at dose of $200 \mathrm{ml} / \mathrm{kg}$ caused increases $41.68 \%$ in Ca content. The lowest mean value in terms of $\mathrm{Mg}$ content was observed in plants with WPP application. A significant decrease was observed in $S$ content of the plants with the increasing use of NDWP $(\mathrm{p}<0.01)$. The usage doses of WPP solution provided S contents that were close to one another, whereas the use of 50\% DWP did not reveal a significant difference. The highest mean $\mathrm{Zn}$ value was observed in plants with the use of NDWP solution. In terms of $\mathrm{Cu}$ content, a difference was observed in plants only through NDWP application depending on the doses applied. The highest L value (brightness) was observed in plants with 50\% DWP application (Figure 2). The use of 50\% DWP caused an increase in the brightness values of the plants up to a usage of $150 \mathrm{ml} / \mathrm{kg}$. The use of NDWP solution caused a sharp decrease in the brightness values of the plants. Color values could not be measured for the $200 \mathrm{ml} / \mathrm{kg}$ soil NDWP application due to the death of the plants. The a values of the plants showed significant differences depending on the whey solutions applied to the plants.

All doses of 50\% DWP solution resulted in a greener leaf color compared to those of the control group samples. An increase was observed in the red color intensity of the leaves with increasing doses of NDWP. The highest red color intensity was determined in plant leaves with $150 \mathrm{ml} / \mathrm{kg}$ NDWP application. All uses of WPP solution resulted in higher green color intensity compared to control except for the $50 \mathrm{ml} / \mathrm{kg}$ dose. The $\mathrm{b}$ values of the leaves increased in plants with increasing doses of 50\% DWP and WPP solutions. It was found that the leaves had the highest yellow color intensity with the use of $50 \%$ DWP solution. A decrease was observed in b values depending on the use of NDWP solution. 


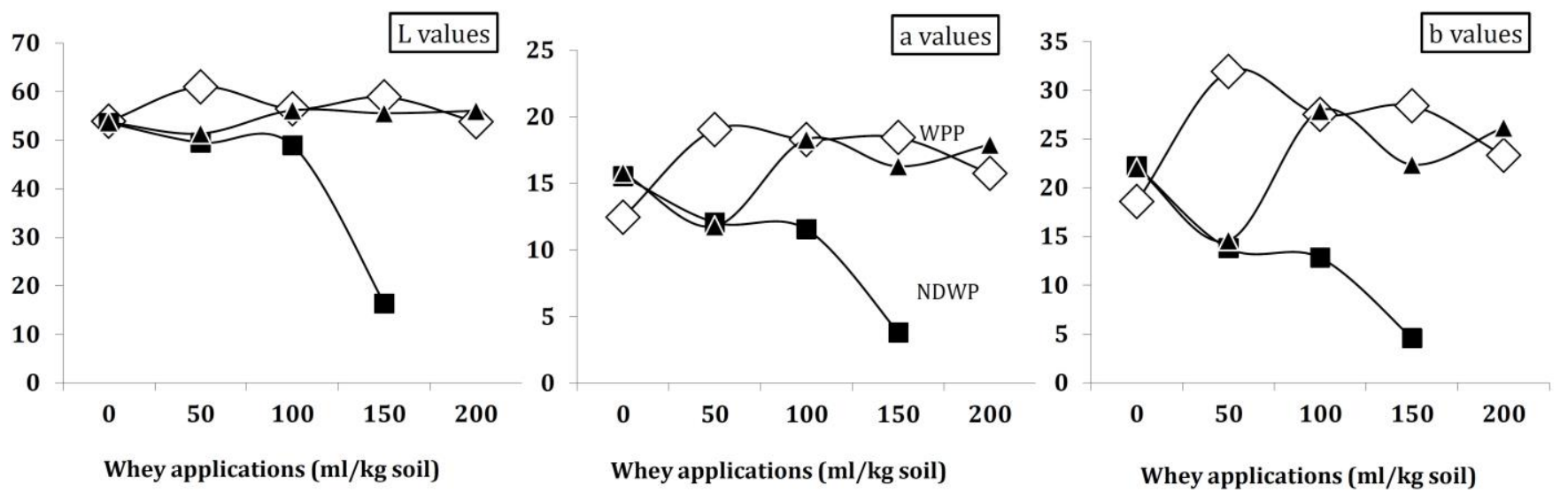

Figure 2. The effect of whey solutions on plant leaf color

\section{Discussion}

Increases between $40.63-47.53 \%$ were observed in microbial biomass $\mathrm{C}$ ratio depending on the usage rate of 50\% DWP solution. The highest mean microbial biomass was determined in soils with 50\% DWP and WPP application. In contrast to other solutions, microbial biomass significantly decreased depending on the usage rate of NDWP $(p<0.01)$. This byproduct, which pollutes the environment and negatively affects plant and animal life by consuming the oxygen in the water when dumped into rivers or lakes, should be used with utmost care when being used as fertilizer in fields and pasture lands, because if whey is not applied to the soil in a careful and controlled way, it could cause cereal plants or pasture grass to stay thin and weak depending on climate, geographical structure and soil properties. For this reason, it is pointed out that it would be correct to apply whey to pasture lands and soil in periods when rainfall is plentiful, like spring (Konar and Arioglu, 1987).

It was reported that whey brought an increase in yield, improved soil structure, and increased the water holding capacity and porosity of the soil (Watson, 1978; Sienkiewicz and Riedel, 1990), increased aggregate stability and infiltration rate in sodic soils (Watson et al., 1977; Lehrsch et al., 1994) and acidic soils (Kelling and Peterson, 1981). Whey applications maintained higher soil biomass-C contents and Cmic/Corg ratio compared to that of straw and vegetable oil; furthermore, fungal contributions to biomass-C dominated over bacterial contributions in whey and straw-amended soil (Sonnleitner et al., 2003a). Protein N existing in whey is converted into inorganic nitrogen in soil and can be used by plants. Besides, whey is rich in nutrients and certain carbon compounds like lactose and is an energy source for microorganisms (Morris 1985; Morissey, 1985). It was reported in certain studies that whey increases the bacterial and fungal population

in the soil (Sonnleitner et al., 2003a,b). Acid whey can also improve the physical condition of sodic soil (Robbins and Lehrsch, 1992). Addition of whey soluble salts to the soil solution should reduce the diffuse double-layer thicknesses of clay domains, thus encouraging clay flocculation (Lehrsch et al., 1993). This improved aggregation will increase the proportion of larger soil pores thereby increasing the flux density of both water and air through the soil profile (Hillel, 1982). Stimulation of aerobic microbiological activity by adding and incorporating whey lactose will produce polysaccharides that will stabilize aggregates (Allison, 1968). Bridges of divalent cations and organic matter (Edwards and Bremner, 1967) will bond soil particles to one another, also increasing aggregate stability. The use of NDWP and WPP solutions did not have an effect on the K content of the plants ( $p>0.01$ ). The use of 50\% DWP solution at doses of 100-150 ml/kg soil maintained a higher $\mathrm{K}$ accumulation compared to that of the control group. The $\mathrm{Ca}^{2+}, \mathrm{Mg}^{2+}$ and $\mathrm{K}^{+}$in the whey will also tend to lower the soil solution $\mathrm{pH}$ since they are not hydrated at low ionic strengths as is $\mathrm{Na}^{+}$. All of these processes will speed the leaching of exchangeable Na from a sodic soil profile when sufficient water is passed through the soil. The lowered $\mathrm{pH}$ will make most micronutrient cations more available to plants grown on the reclaimed site. In addition, micronutrients in the applied whey (Radford et al., 1986) should be available to crops. It should not be forgotten that in case whey is dumped into the environment without being refined, this process should be carried out under control; the amount of protein nitrogen that will be obtained from whey should be calculated so that nitrogenous fertilizer is not given more than the plant needs during the chemical fertilization process and excessive nitrogen might cause pollution problems. As it was also found in the present study, whey has a positive effect on soil biological properties. In conclusion, we can say that this waste product, which has high nutrient element content, could be used in fertilization practices especially as a nitrogen source and multi-perspective studies need to be carried out on this topic. 


\section{References}

Allison, F.E., 1968. Soil aggregation - Some facts and fallacies as seen by a microbiologist. Soil Science 106(2): 136-143.

Anderson, J.P.E., 1982. Soil respiration. In. Methods of soil analysis, Part 2- Chemical and Microbiological Properties, Page, A.L., Keeney, D. R., Baker, D.E., Miller, R.H., Ellis, R. Jr., Rhoades, J.D. (Eds.). ASA-SSSA, Madison, Wisconsin, USA. pp. 831-871.

Anderson, J.P.E., Domsch, K.H., 1978. A physiological method for the quantitative measurement of microbial biomass in soils. Soil Biology and Biochemistry 10(3): 215-221.

Anonymous, 1998. Mineral matter analysis. CEM Corporation, 3100 Smith Form Road Mtthews, NC. USA.

Beck, T.H., 1971. Die messung der katalaseaktivität von böden. Zeitschrift für Pflanzenernährung und Bodenkunde 130(1): 68-81.

Edwards, A.P., Bremner, J.M., 1967. Microaggregates in soils. European Journal of Soil Science 18(1): 64-73.

Hillel, D. ,1982. Introduction to Soil physics. Academic Press, New York. USA. 364p.

Jones Jr, J.B., 2001. Laboratory Guide for Conducting Soil Test and Plant Analysis. CRC Press, Washington DC, USA. 363p.

Jones, S.B., Robbins, C.W. , Hansen, C.L., 1993. Sodic soil reclamation using cottage cheese (acid) whey. Arid Soil Research and Rehabilitation 7(1): 51-61.

Kelling, K.A., Peterson, A.E., 1981. Using whey on agricultural land-A disposal alternative. Extension Bulletin A3098, University of Wisconsin, Madison, WI, USA.

Konar, A., Arioglu, H., 1987. Research Notes : Turkey : Effect of cheese whey as a fertilizer on the increase of soybean nodules. Soybean Genetics Newsletter: Vol. 14, Article 32. Available at [Access date: 10.08.2019]: http://lib.dr.iastate.edu/soybeangenetics/vol14/iss1/32

Lehrsch, G.A., Robbins, C.W., Hansen, C.L., 1994. Cottage cheese (acid) whey effects on sodic soil aggregate stability. Arid Soil Research and Rehabilitation 8(1): 19-31.

Lehrsch, G.A., Sojka, R.E., Jolley, P.M., 1993. Freezing effects on aggregate stability of soils amended with lime and gypsum. In: Soil surface sealing. Poesen, J.W.A., Nearing, M.A. (Ed.). Catena Supplement, No. 24. Catena Verlag, Germany. pp. 115-127. Available at [Access date: 10.08.2019]: https://eprints.nwisrl.ars.usda.gov/781/

Morissey, P.A., 1985. Lactose chemical and physicochemical properties. In: Fox, P.F. (Ed.). Developments in Dairy Chemistry-3. Lactose and Minor Constituents, Springer. pp. 1-34.

Morris, S., 1985. Whey, Feed or Fertilizer. Proceed of the Ruakura Farmer's Conference, New Zealand. 37: 113-116.

Naik, Y.K., Khare, A., Choudhary, P.L., Goel, B.K., Shrivastava, A., 2009. Studies on physico-chemical and sensory characteristics of whey based watermelon beverage. Asian Journal of Research Chemistry 2(1): 57-59.

Özrenk, E., Demir, S., Tüfenkçi, S., 2003. The effects of whey application and inoculations of Glomus intraradices and Rhizobium cicer on the some growth parameters of chickpea. Yüzüncü Yll Üniversitesi, Ziraat Fakültesi, Tarım Bilimleri Dergisi 13(2): 127-132. [in Turkish]

Pepper, I.L., Gerba, C.P., Brendecke, J.W., 1995. Environmental Microbiology: A Laboratory Manual. Academic Press Inc.

Peterson, A.E., Walker, W.G., Watson, K.S., 1979. Effect of whey applications on chemical properties of soils and crops. Journal of Agricultural and Food Chemistry 27(4): 654-658.

Radford, J.B., Galpin, D.B., Parkin, M.F., 1986. Utilization of whey as a fertilizer replacement for dairy pasture. New Zealand Journal of Dairy Science and Technology 21: 65-72.

Reddy, G.V., Deshmukh, V.R., Joshi, R.N., Kayama, R., 1987. Utilization of alfalfa (mediacago sativa l.) whey as a fertilizer in irrigation. Japanese Journal of Grassland Science 33(1): 32-37.

Robbins, C.W., Hansen, C.L., Roginske, M.F., Sorensen, D.L., 1996. Phosphorus status of calcareous and sodic soils treated with cheese whey. Transactions of the ASAE 40(1): 143-148.

Robbins, C.W., Lehrsch, G.A., 1992. Effects of acidic cottage cheese whey on chemical and physical properties of a sodic soil. Arid Soil Research and Rehabilitation 6(2): 127-134.

Ryder, D.N., 1980. Economic considerations of whey processing. International Journal of Dairy Technology 33(2): 73-77.

Sharratt, W.J., Peterson, A.E., Calbert, H.E., 1962. Effects of whey on soil and plant growth. Agronomy Journal 54(4): 359-361.

Sienkiewicz, T., Riedel, C.L., 1990. Whey and whey utilization : possibilities for utilization in agriculture and foodstuffs production. Gelsenkirchen-Buer: Verlag Th. Mann, Berlin, Germany. 379p.

Sonnleitner, R., Lorbeer, E., Schinner, F., 2003a. Monitoring of changes in physical and microbiological properties of a Chernozem amended with different organic substrates. Plant and Soil 253: 391-402.

Sonnleitner, R., Lorbeer, E., Schinner, F., 2003b. Effects of straw, vegetable oil and whey on physical and microbiological properties of a chernozem. Applied Soil Ecology 22(3): 195-204.

TUIK, 2012. Süt Ürünleri Üretim İstatistikleri. [in Turkish]

Watson, K.S., 1978. Continuing impact of the environmental era on the dairy industry. Proocedings Whey Products Conference Minneapolis-Minnesota, pp.30-52.

Watson, K.S., Peterson, A.E., Powell, R.D., 1977. Benefits of spreading whey on agricultural land. Water Pollution Control Federation 49(1): 24-34.

Wendorff, W., 2012. Uses of Whey in the Farmstead Setting. Wisconsin Department of Agriculture. Trade and Consumer Protection, The Dairy Business Innovation Center. Madison, USA.

Wrolstad, R.E., Smith, D.E., 2014. Color Analysis. In: Food Analysis. Nielsen S.S. (Ed.). Springer NY, USA. pp.573-586.

Yurtsever, N., 1984. Experimental statistical methods. T.C. Ministry of Agriculture and Forestry, Pub.No: 121. Ankara, Turkey, 623p. [in Turkish] 